\title{
Central pain due to stroke: cognitive representation and coping according to gender
}

\author{
Dor central em acidente vascular encefálico: representação cognitiva e \\ enfrentamento conforme o gênero
}

Mariana Nogueira ${ }^{1}$, Manoel Jacobsen Teixeira ${ }^{2}$

\begin{abstract}
Objective: To identify and compare perceptions of pain and how it is faced between men and women with central post-stroke pain. Methods: The participants were 25 men and 25 women of minimum age 30 years-old and minimum schooling level of four years, presenting central post-stroke pain for at least three months. The instruments used were: Mini-Mental State Examination; structured interview for the Brief Psychiatric Scale; Survey of Sociodemographic and Clinical Data; Visual Analogue Scale (VAS); Ways of Coping with Problems Scale (WCPS) in Scale; Revised Illness Perception Questionnaire (IPQ-R); and Beck Depression Inventory (BDI). Results: A significantly greater number of women used the coping strategy "Turn to spiritual and religious activities" in WCPS. They associated their emotional state with the cause of pain in IPQ-R. "Distraction of attention" was the strategy most used by the subjects. Conclusion: Women used spiritual and religious activities more as a coping strategy and perceived their emotional state as the cause of pain.
\end{abstract}

Key words: central pain, gender identity, cognition, stroke.

\section{RESUMO}

Objetivo: Identificar e comparar a percepção e o enfrentamento da dor entre homens e mulheres com dor central por acidente vascular cerebral (AVC). Métodos: Participaram do estudo 25 homens e 25 mulheres com dor central por AVC há pelo menos três meses, maiores de 30 anos, escolaridade mínima de $4^{\mathrm{a}}$ série. Os instrumentos utilizados foram: Mini-exame do Estado Mental; Entrevista Estruturada para Escala Psiquiátrica Breve; Inquérito de Dados Sociodemográficos e Clínicos; Escala Visual Analógica (EVA); Escala dos Modos de Enfrentamento de Problemas (EMEP); Questionário de Percepção da Doença Revisado (QPD-R) e Inventário de Depressão de Beck (IDB). Resultados: Um número significativamente maior de mulheres revelou usar a estratégia de enfrentamento "Realizar atividades espirituais e religiosas" na EMEP e associou o estado emocional à causa de suas dores no QPD-R. "Distração da atenção" foi a estratégia mais utilizada pelos sujeitos. Conclusão: As mulheres utilizaram mais atividades espirituais e religiosas como estratégia de enfrentamento e perceberam mais o estado emocional como causa da dor.

Palavras-Chave: dor central, identidade de gênero, cognição, acidente vascular cerebral.

Central pain is a regional pain caused by a primary lesion or dysfunction in the central nervous system, usually associated with abnormal sensitivity to temperature and noxious stimulation ${ }^{1}$. Changes in temperature, emotional stress, and movement usually increase the pain ${ }^{2}$. Cerebrovascular lesions (strokes or hemorrhages), multiple sclerosis, and spinal cord injuries are the most common causes ${ }^{1}$.

This pain is intense, constant and it usually burns. It is a physical and psychological aggravating for most patients. In consequence, their social lives and work are often very much impaired ${ }^{2}$. Central pain causes many changes in people's lives, and so they have to try different cognitive and behavioral strategies to deal with the pain and its effects ${ }^{3}$.

The coping process has the aim of dealing with two main functions: to manage or change the problems in the environment to modify the stressful situation (problem-centered coping); and to control the disturbance or discomfort associated with the stressful situation without changing the situation itself (emotion-centered coping) ${ }^{4}$.

\footnotetext{
${ }^{1}$ MSc, Psychologist and Specialist in Health Psychology, Neurology Department, University of São Paulo Medical School, São Paulo SP, Brazil;

${ }^{2} \mathrm{MD}$, PhD, Chairman and Director, Division of Neurological Surgery, University of São Paulo Medical School, São Paulo SP, Brazil.

Correspondence: Mariana Nogueira;Avenida Getúlio Vargas 1.377; 13976-400 Itapira SP - Brasil; E-mail: nogueiramariana@yahoo.com.br

Support: Fundação de Amparo à Pesquisa do Estado de São Paulo FAPESP, Brazil.

Conflict of interest: There is no conflict of interest to declare
}

Received 13 December 2010; Received in final form 21 October 2011; Accepted 28 October 2011 
Men and women deal differently with stressful life events ${ }^{5}$. Women with pain use a lot of coping strategies ${ }^{6}$, although men gain greater benefit from the strategy of "focus attention on the pain"?

The literature shows that men and women have different perceptions on the cause of chronic pain. Men perceive pain as something external to them and attribute it to external events, while women attribute the cause of pain to the internal ones ${ }^{8}$.

The aims of this study were to identify and compare the coping strategies used by men and women with central poststroke pain and also the perceptions that men and women have of central pain.

\section{METHODS}

This study was conducted at the Multidisciplinary Pain Center of the Department of Neurology, Hospital das Clínicas, University of São Paulo Medical School, in Brazil.

Fifty subjects (25 men and 25 women), who had been diagnosed with central pain due to ischemic or hemorrhagic stroke for at least three months, participated in the study. The inclusion criteria were that patients should have a minimum age of 30 years-old, a minimum of four years of basic schooling and presence of central post-stroke pain for at least three months. The exclusion criteria were: presence of cognitive or language impairment and of psychotic symptoms.

This study was approved by the Central Research Division of the Institute of Psychology and the Ethics Committee for Research Project Analysis of Hospital das Clínicas, University of São Paulo Medical School.

The instruments used in this study were: Mini-Mental State Examination ${ }^{9}$ validated for Brazil ${ }^{10}$, in order to assess the presence of cognitive impairment; Structured Clinical Interview for the Brief Psychiatric Scale ${ }^{11}$ adapted for the Brazilian population ${ }^{12}$, in order to identify psychotic symptoms; Survey of Demographics and Clinical Data; Visual Analogue Scale (VAS) ${ }^{13}$, in order to measure pain intensity; Beck Depression Inventory (BDI) ${ }^{14}$ validated for the Brazilian population $^{15}$, in order to identify depression symptoms; Ways of Coping with Problems Scale (WCPS) ${ }^{16}$ adapted for the Brazilian population ${ }^{17}$, composed of 45 items that assess four coping strategies ("Problem-focused coping", "Emotionfocused coping", "Search for religious practices and wishful thinking" and "Search for social support"), and an open question about how the subject does to deal with the pain; and Revised Illness Perception Questionnaire (IPQ-R) ${ }^{18}$ translated into Portuguese ${ }^{19}$, in order to assess perceptions of disease according to five basic components: identity, causes, consequences, evolution, and cure/control. The IPQ-R scale was divided into three fields. The first included the identity component; the second included duration (acute/chronic), consequences, personal control, treatment control, cyclic duration, illness coherence and emotional representation, and the third one showed aspects of the causes.

After reviewing the subjects' records in order to ascertain whether any inclusion or exclusion factors were present, and to collect demographic and clinical information that shaped the diagnosis of stroke, individuals who initially fulfilled the criteria were assessed cognitively using the Mini-Mental State Examination and answered the questions of the Structured Clinical Interview for the Brief Psychiatric Rating Scale. Subjects who scored less than 24 points in the Mini-Mental State Examination and showed symptoms of psychotic disorder were excluded from the survey. Subjects who scored more than 24 points in the Mini-Mental State Examination and showed no symptoms of psychotic disorder were eligible to provide answers to other instruments.

After the investigators had explained what the research consisted of and after the patients had signed the informed consent statement, the other research instruments were applied. The patients gave responses in the presence of the researcher. It took approximately 90 minutes to implement these tests.

Firstly, they answered a questionnaire seeking demographic and clinical data, and they quantified the intensity of their pain using the VAS. Following this, they gave responses for the WCPS, and then the IPQ-R and BDI.

\section{Statistical analysis}

All the information collected was organized into an electronic database and was analyzed using the tools available in the Statistical Package for the Social Sciences, version 12.0. The Student's $t$-test was used on quantitative variables and the $\chi^{2}$ test was used to compare qualitative variables. This study used a significance level of 0.05 .

\section{RESULTS}

The men's mean age was 59.6 years-old and the women's was 53.5 years-old. The mean length of time with pain was 94.7 months among the men and 82.7 months among women. Moreover, $92 \%$ of subjects had had ischemic stroke. Table 1 shows the demographic and clinical data.

Table 1 also shows that the percentage of married men was higher (84\%) than the one of married women (52\%). The statistical analysis showed this difference in men and women's marital status was significant ( $\mathrm{p}=0.015)$.

The mean VAS score among women was higher (7.1) than that of men (6.0), but without any statistically significant differences $(p=0.133)$.

The WCPS assesses the frequencies of the four coping strategies. There was a statistically significant difference between men and women in relation to "Search for religious 
practices and wishful thinking”, which the women reported using more frequently (Table 2).

In the open question that is part of the WCPS, the coping strategies mentioned by the subjects were divided into two groups: "Problem-centered coping" ("Seek treatment for pain", "Pretend not to feel the pain", "Ignore the pain" or "Accept the disability due to the pain") and "Emotioncentered coping" ("Distraction of attention", "Self-assertion of coping", "Control of emotions", "Turn to spiritual and religious activities" and "Seek social support"). Table 3 shows the numbers of responses from men and women for each coping strategy.

As shown in Table 3, there was a statistically significant difference between men and women in relation to the coping strategy "Turn to spiritual and religious activities" $(\mathrm{p}=0.025)$. The women in this study used this strategy more than the men.

The strategy most mentioned by the subjects (16 men and 16 women) was "Distraction of attention".

In the IPQ-R, there was a statistically significant difference $(0.023)$ between men and women in relation to emotional factors as the cause of pain. A greater number of women (18) than men (10) linked their emotional state to the pain.

Table 1. Distribution of men and women according to demographic and clinical data in numbers and percentages.

\begin{tabular}{|c|c|c|c|c|c|}
\hline Variables & $\begin{array}{l}\text { Men } \\
(n)\end{array}$ & $\begin{array}{l}\text { Men } \\
(\%)\end{array}$ & $\begin{array}{c}\text { Women } \\
(\mathrm{n})\end{array}$ & $\begin{array}{c}\text { Women } \\
(\%)\end{array}$ & $\mathrm{p}$ \\
\hline Marital status & & & & & 0.015 \\
\hline Married & 21 & 84 & 13 & 52 & \\
\hline Others & 4 & 16 & 12 & 48 & \\
\hline Education level & & & & & 0.088 \\
\hline Primary school & 14 & 56 & 6 & 24 & \\
\hline High school & 5 & 20 & 12 & 48 & \\
\hline University & 6 & 24 & 7 & 28 & \\
\hline Religion & & & & & 0.823 \\
\hline None & 2 & 8 & 2 & 8 & \\
\hline Catholic & 14 & 56 & 13 & 52 & \\
\hline Others & 9 & 36 & 10 & 40 & \\
\hline Professional activities & & & & & 0.320 \\
\hline On sick leave due to pain & 4 & 16 & 5 & 20 & \\
\hline Retired & 15 & 60 & 11 & 44 & \\
\hline Unemployed & 1 & 4 & 5 & 20 & \\
\hline Currently working & 5 & 20 & 4 & 16 & \\
\hline Occupation before the pain & & & & & 0.506 \\
\hline Was working & 21 & 84 & 22 & 88 & \\
\hline Retired & 2 & 8 & 0 & 0 & \\
\hline On sick leave due to pain & 1 & 4 & 0 & 0 & \\
\hline Unemployed & 1 & 4 & 3 & 12 & \\
\hline
\end{tabular}

The results from the BDI showed that the women's score (18.5) was higher than the men's (16.8), but there was no statistically significant difference between the two groups ( $\mathrm{p}=0.498$ ).

\section{DISCUSSION}

In the demographic and clinical data, there was a statistically significant difference between men and women in relation to marital status, such that more men than women were married. This difference might be explained by the fact that Brazilian men have more chronic disease and die earlier than Brazilian women ${ }^{20}$.

From analyzing occupational data before and after the pain, it was found that the percentage of subjects who had an occupation before they started to have central pain was $86 \%$ and the percentage of subjects who had an occupation at the time of the survey was $18 \%$. Regarding the emotional domain of the BDI, the mean score was 16.8 among the men and 18.5 among the women, thus corresponding to mild symptoms of depression. These results show that central post-stroke pain is a great physical and psychological burden on most patients.

Table 2. Distribution of the two genders regarding means and significance levels ( $p$ ) of frequencies of using coping strategies, as measured by the Ways of Coping with Problems Scale.

\begin{tabular}{lccc} 
Coping strategies & $\begin{array}{c}\text { Men } \\
\text { (mean) }\end{array}$ & $\begin{array}{c}\text { Women } \\
\text { (mean) }\end{array}$ & $\begin{array}{c}t \text { test } \\
\text { p }\end{array}$ \\
\hline Problem-centered coping & 3.7 & 3.7 & 0.661 \\
Emotion-centered coping & 2.3 & 2.2 & 0.545 \\
$\begin{array}{l}\text { Search for religious practices } \\
\text { and fantasized thoughts }\end{array}$ & 3.4 & 4 & 0.034 \\
\begin{tabular}{l} 
Search for social support \\
\hline
\end{tabular}
\end{tabular}

Table 3. Distribution of men and women regarding means and significance levels ( $p$ ) of frequencies of using coping strategies, as measured by the open question in the Ways of Coping with Problems Scale.

\begin{tabular}{cccc} 
& Male & Female & Fisher test \\
Coping strategies & $(n)$ & $(n)$ & $p$ \\
\hline
\end{tabular}

Problem-centered

$\begin{array}{llll}\text { Seek treatment for pain } & 10 & 10 & 0.613 \\ \text { Pretend not to feel pain } & 0 & 3 & 0.117 \\ \text { Ignore the pain } & 3 & 5 & 0.351 \\ \text { Accept the disability due to pain } & 1 & 1 & 0.500\end{array}$

Emotional-centered

$\begin{array}{llll}\text { Distraction of attention } & 16 & 16 & 0.616 \\ \text { Self-assertion of coping } & 3 & 1 & 0.305 \\ \text { Control of emotions } & 2 & 2 & 0.695 \\ \text { Turn to spiritual and religious activities } & 0 & 5 & 0.025 \\ \text { Seek social support } & 5 & 6 & 0.500\end{array}$


Their social life and work are often very much impaired, thus causing great suffering and impaired quality of life ${ }^{2}$.

Strokes cause functional and physical damage that may interfere in coping and pain perception. In this study, the physical and functional repercussions were not measured or controlled for which may have influenced the results.

The intensity of pain among the women was an average of 7.1 on the VAS, while for men it was 6.0. However, there was no statistically significant difference in these findings. This fact contradicts some studies, which showed that women complained more about pain, and they showed greater sensitivity and lower pain tolerance than men $^{21-23}$.

The WCPS showed a statistically significant difference between men and women in relation to the frequency of use of the strategy "Search for religious practices and wishful thinking”, which was used more often by women. In the open question, categories of coping were created, and there was a statistically significant difference between men and women who "Turn to spiritual and religious activities". These results proved that women use spiritual and religious activities more often than men do. Brazilian women are more religious than men; $5.7 \%$ of Brazilian women do not have a religious belief versus $9 \%$ of Brazilian men ${ }^{24}$.

In the open question of the WCPS, the coping strategy most mentioned by the subjects was "Distraction of attention". In one study, in which the objective was to identify the coping strategies used by subjects with long-term pain, it was found that "Distraction of attention" was one of the most used coping strategies ${ }^{25}$. Another study showed that the coping strategy of "Distraction of attention" was more effective than "Focus attention on pain" ${ }^{26}$.

Regarding the cause domain of the IPQ-R, women associated their emotional state with the cause of pain more than men did. Men understand pain as something external to them and attributed it to "external" events, whereas women attributed it to "internal" ones 8 .

The results proved that, among subjects with central pain, women use spiritual and religious activities more as coping strategies. They also associate their emotional state with pain more than men do.

\section{References}

1. Merskey H, Bogduck N. Classification of chronic pain. $2^{\mathrm{a}}$ ed. Seattle, Washington: IASP Press; 1994.

2. Oliveira RAA.Dorcentral na doençavascularencefálica:caracterização de uma amostra e correlação das variáveis clínicas da expressão somática da dor com as imagens do encéfalo. [dissertation]. São Paulo: School of Medicine, University of São Paulo; 2001.

3. Portnoi AG. $O$ enfrentamento da dor. In: Teixeira MJ, Braun JL, Marquez JO (Eds). Dor: Contexto Interdisciplinar. Curitiba: Mayo; 2003: 205-212.

4. Lazarus RS, Folkman S. Stress, Appraisal, and Coping. New York: Springer; 1984.

5. Affleck G, Tennen H, Keefe FJ, et al. Everyday life with osteoarthritis or rheumatoid arthritis: independent effects of disease and gender on daily pain, mood, and coping. Pain 1999;83:601-609.

6. Unruh AM, Ritchie J, Merskey H. Does gender affect appraisal of pain and pain coping strategies? Clin J Pain 1999;15:31-40.

7. Jensen IB, Bergström G, Ljungquist T, Bodin T, Nygren AL. A randomized controlled component analyses of a behavioral medicine rehabilitation program for chronic spinal pain: are de effects dependent on gender? Pain 2001;91:65-78.

8. Nogueira M, Portnoi AG, Okada M, Teixeira MJ, Casetto SJ. As diferenças entre homens e mulheres no enfrentamento da dor. Dor 2008;9:1242-1252.

9. Folstein MF, Folstein SE, McHugh PR. "Mini-mental state". A practical method for grading the cognitive state of patients for the clinician. $J$ Psychiatr Res 1975;12:189-198.

10. Bertolucci PHF, Brucki SMD, Campacci S, et al. O Mini-Exame do Estado Mental em uma população geral: impacto da escolaridade. Arq Neuropsiquiatr 1994;52:1-7.

11. Rhoades HM, Overall JE. The semistructured BPRS interview and rating guide. Psychopharm Bulletin 1988;24:101-104.

12. Crippa JAS, HallakJEC, Sanches RF, Loureiro SR, Zuardi AW. Roteiro de entrevista estruturada para a Escala Breve de Avaliação Psiquiátrica (SIG-BPRS). In: Gorenstein C, Andrade LHSG, Zuardi AW (Eds). Escalas de Avaliação Clínica em Psiquiatria e Psicofarmacologia. São Paulo: Lemos; 1999:207-217.
13. Jensen MP, Karoly P. Pain-specific beliefs, perceived symptom severity, and adjustment to chronic pain. Clin J Pain 1992;8:123-130.

14. Beck AT, Ward CH, Mendelson M, Mock J, Erbaugh J. An inventory for measuring depression. Arch Gen Psychiatry 1961;4:561-571.

15. Gorenstein C, Andrade L. Validation of a Portuguese version of the Beck Depression Inventory and State-Trait Anxiety Inventory in Brazilian subjects. Braz J Med Biol Res 1996;29:453-457.

16. Vitaliano PP, Russo J, Carr JE, Maiuro RD, Becker J. The ways of coping checklist: revision and psychometric properties. Multivariate Behav Res 1985;20:3-26.

17. Gimenes MGG, Queiroz B. As diferentes fases de enfrentamento durante o primeiro ano após a mastectomia. In: Gimenes MGG, Fávero MH (Eds). A mulher e o câncer. Campinas: Editorial Psy; 1997:171195.

18. Weinman J, Petrie KJ, Moss-Morris R, Horne R. The illness perception questionnaire: a new method fot assessing the cognitive representation of illness. Psychol Health 1996;11:431-435.

19. Moss-Morris R, Weinman J, Petrie KJ, Horne R, Cameron LD, Buick D. The Revised Illness Perception Questionnaire (IPQ-R). Psychol Health 2002;17:1-16.

20. Figueiredo W. Assistência à saúde dos homens: um desafio para os serviços de atenção primária. Cienc Saúde Col 2005;10:105-109.

21. Myers CD, Riley JL, Robinson ME. Psychosocial Contributions to SexCorrelated Differences in Pain. Clin J Pain 2003;19:225-232.

22. Fillimgim RB. Sex-Related influences on pain: a review of mechanisms and clinical implications. Reab Psychol 2003;48:165-174.

23. Unruh AM. Gender variations in clinical pain experience. Pain 1996;65:123-167.

24. Neri CM. A ética católica e o espírito da revolução feminina. 2005. [Internet] [cited $2010 \mathrm{Jul}$ 9]. Available from: http://www.fgv.br/cps/ religioes/Apresenta\%E7\%E3o/valor.pdf.

25. Widar M, Anna-Cristina EK, Ahlstro G. Coping with long-term pain after a stroke. J Pain Symptom Manag 2004;27:215-225.

26. McCaul CH.Attention, distraction, and cold-pressor pain.J Personality Social Psychol 1982;43:154-162. 